\title{
Oficina Terapêutica de Criatividade em Unidade de Internação - uma Experiência em Hospital Oncológico
}

\author{
Pinto, Stela Duarte; Simões, Mariana Meloni Mathias; Britto, Mariana G. Dafonseca de \\ Instituto do Câncer do Estado de São Paulo — stela.duarte@icesp.org.br
}

Introdução: a Oficina Terapêutica de Criatividade em hospital oncológico visa promover a possibilidade de expressão e elaboração de sentimentos e emoções suscitados pelo processo de adoecimento, por meio de recursos artísticos diversos, buscando acessar e trabalhar conteúdos psíquicos. Pode ser considerada uma ação humanizada, à medida que propicia um espaço aberto à reflexão e estimula o paciente a ser um agente transformador frente ao seu processo de enfermidade; além de ser um grupo de suporte e apoio, com cunho terapêutico, pois proporciona a oportunidade de partilhar experiências, à medida que é composta por pessoas vivendo situações semelhantes. Pode ser excelente recurso terapêutico coadjuvante para lidar com pessoas que vivem situações de crise, promover coesão e apoio, elevar a autoestima e autoconfiança dos pacientes. Objetivo: Fortalecer rede de apoio, visando à diminuição do impacto da hospitalização e tratamento, na busca de promoção de qualidade de vida; permitir a reflexão sobre si mesmo, para uma possível reorganização interna e reconstrução da realidade; auxiliar na diminuição do impacto das repercussões e mudanças advindas do adoecimento e tratamento, por meio do fortalecimento de recursos de enfrentamento. Método: São utilizadas atividades semi dirigidas, tendo como foco fortalecer os recursos de enfrentamento frente à vivência do adoecer e hospitalização. como recursos artísticos, são disponibilizados materiais áudio visuais e gráficos. Esta atividade é realizada semanalmente, em unidades de internação, de um hospital oncológico público, sob a coordenação de um psicólogo. É possível que 10 pacientes participem do grupo, após serem avaliados e liberados pela equipe de enfermagem; o grupo tem duração de uma hora. É aplicada a escala visual analógica (EVA), antes e depois da atividade, com a finalidade de avaliar o bem estar do paciente quanto à efetividade da proposta. Resultados: a Oficina Terapêutica de Criatividade iniciou-se em abril de 2013, e, desde então, atendeu a 49 pacientes. Destes, 48 sentiram-se satisfeitos e ajudados após o grupo, diminuindo seu grau de desconforto emocional. Apenas um participante referiu que seu desconforto emocional era zero (0) no início e no fim do grupo, portanto, a oficina não modificou seu bem estar. Quatorze pacientes relataram que a Oficina Terapêutica de Criatividade ajudou através da possibilidade de serem ouvidos e de ouvir a experiência do outro. Conclusão: Pode-se considerar que esta atividade com recursos artísticos propicia um aumento da sensação de bem estar, favorecendo a troca de experiências entre os pacientes e a expressão de sentimentos relacionados ao adoecer. Desta forma tem sido importante a prática desta atividade, contribuindo para um trabalho mais humanizado, no qual o paciente é percebido e respeitado em sua totalidade.

Pinto, Stela Duarte; Simões, Mariana Meloni Mathias; Britto, Mariana G. Dafonseca de. Oficina Terapêutica de Criatividade em Unidade de Internação - uma Experiência em Hospital Oncológico. In: Anais do Congresso Internacional de Humanidades \& Humanização em Saúde [= Blucher Medical Proceedings, num.2, vol.1]. São Paulo: Editora Blucher, 2014. ISSN 2357-7282

DOI 10.5151/medpro-cihhs-10793 